\title{
The analysis of spatial and temporal changes of land cover and land use in the reclaimed areas with the application of airborne orthophotomaps and LANDSAT images
}

\author{
Marta Szostak ${ }^{1}$, Piotr Wężyk ${ }^{1}$, Paweł Hawryło', \\ Marcin Pietrzykowski \\ ${ }^{1}$ University of Agriculture in Krakow, Faculty of Forestry \\ Institute of Forest Resources Management, \\ Department of Forest Management, Geomatics and Forest Economics - Laboratory of Geomatics \\ Aleja 29 Listopada 46 , 31-425 Krakow, Poland \\ e-mail: m.szostak@ur.krakow.pl, p.wezyk@ur.krakow.pl,p.hawrylo@ur.krakow.pl \\ ${ }^{2}$ University of Agriculture in Krakow, Faculty of Forestry \\ Institute of Forest Ecology and Silviculture, Department of Forest Ecology and Reclamation \\ Aleja 29 Listopada 46, 31-425 Krakow, Poland \\ e-mail: rlpietrz@cyf-kr.edu.pl
}

Received: 16 October 2014 / Accepted: 12 February 2015

\begin{abstract}
The aim of this study was to investigate the possible use of geoinformatics tools and generally available geodata for mapping land cover/use on the reclaimed areas. The choice of subject was dictated by the growing number of such areas and the related problem of their restoration. Modern technology, including GIS, photogrammetry and remote sensing are relevant in assessing the reclamation effects and monitoring of changes taking place on such sites. The LULC classes mapping, supported with thorough knowledge of the operator, is useful tool for the proper reclamation process evaluation.

The study was performed for two post-mine sites: reclaimed external spoil heap of the sulfur mine Machów and areas after exploitation of sulfur mine Jeziórko, which are located in the Tarnobrzeski district. The research materials consisted of aerial orthophotos, which were the basis of on-screen vectorization; LANDSAT satellite images, which were used in the pixel and object based classification; and the CORINE Land Cover database as a general reference to the global maps of land cover and land use.
\end{abstract}

Keywords: reclamation, GEOBIA, pixel-based classification, LULC changes

\section{Introduction}

Spatial data in the form of up-to-date maps containing the classes of land cover and land use (LULC) are applied in many areas such as: transport, management or forestry. They are irreplaceable source of knowledge about changes taking place in 
the environment. These are both natural processes resulting from climatic conditions as well as anthropogenic influence. Mine workings as a post-industrial landscape are examples of large scale land-transformation. The increase of the areas where the environment was changed as a result of mining and/or other industry is observed. National regulations in Poland (Act on Agricultural and Forest Ground Protection (Polish Law), 1995/1997) require that all mined lands, whether for coal or other minerals, after closing of exploitation must receive reclamation treatments as soon as possible. The purpose of performing treatments is to restore usefulness of degraded areas. In Poland there are about 64 thousand ha of degraded and devastated areas requiring reclamation. In last decades only about 1.8 to 2.7 thousand ha are reclaimed annually.

Changeable forms of land use, as well as more and more heterogenic landscape cause the situation, when modern techniques have greater significance in the studies on progressing changes. Spatial information has its base for doing analyses and provides support in the decision making process. Greater stress is put on the improvement and introduction of novel techniques including geoinformation technologies such as those used in making the LULC change maps (Bergen and Dronova, 2007; Chmielewski et al., 2014; Dudzińska-Nowak and Wężyk, 2013; Szostak et al., 2014; Szostak and Nowicka, 2013). Thery are also used for characterising of the morphometry and determination of the spatial structure of vegetation on the reclaimed post-mining areas (Wężyk et al., 2014). A massive use of geospatial technology in Poland is noticeable, including digital airborne photographs/orthophotomaps, precise measurements using GNSS (Szostak and Wężyk, 2013; Wężyk and Krzaklewski, 1999), remote sensing satellite images (Drzewiecki et al., 2014; Hejmanowska, 2006), or Light Detection and Ranging (LiDAR) technology (Wężyk et al., 2013; Tompalski et al., 2014). The data sets collected with the mentioned technologies are integrated in Geographic Information Systems (GIS) and used for generation of new 2D and 3D spatial information as the useful tool in land management, forestry and reclamation of degraded areas.

As the study area for this work an area changed as a result of industrial activities was selected. The study area covered a part of the areas of the former sulfur mines Jeziórko and Machów, where, after finishing the exploitation, a wide-range reclamation process was carried out. Due to the scale of the project and immense means used for this purpose, it seems reasonable to assess the effects of the carried out reclamation measures, based on the analysis of spatial and temporal changes of land cover and land use in these areas. The goal of this paper was to define the possibilities of using publically available geodata and selected geoinformation techniques such as: pixel-based classification, Geographic Object Based Image Analysis (GEOBIA) and on-screen vectorization in defining the categories of land cover and land use of the reclaimed areas. 


\section{Study Area}

There were two objects of the study - the area of the reclaimed sulfur mine Jeziórko after Frash method exploitation (the analysed area was 216.5 ha and was situated within the limits of the commune of Grębów; given to the jurisdiction of the State Forests Holding - Forest InspectorateNowa Dęba, Forest District Stale) and the reclaimed outer repository of the former open cast sulfur mine Machów (analysed area -871.71 ha in the communes: Baranów Sandomierski and Nowa Dęba) situated in the Tarnobrzeg District, in the Podkarpackie Voivodeship (Fig. 1). The areas were selected because of the reclamation process carried out there, and consequently, dynamic changes in the categories of land cover and land use.
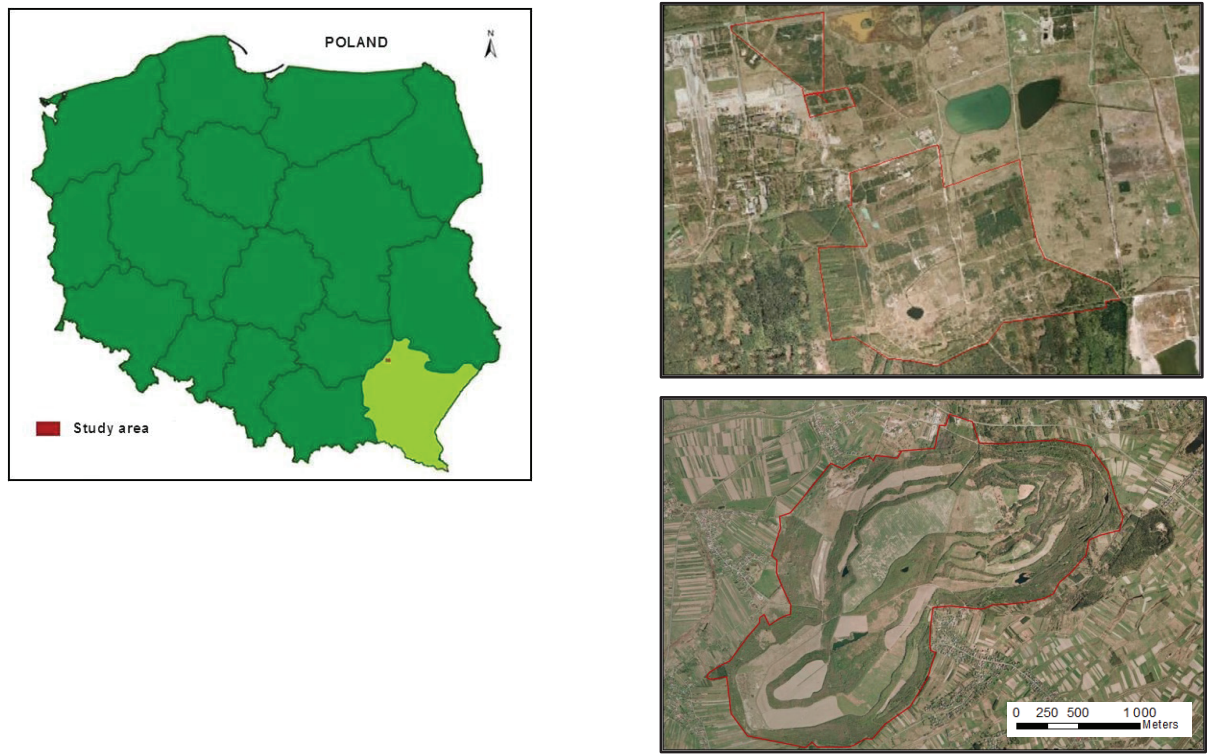

Fig. 1. The study area (left, red rectangle): sulfur mines Jeziórko (top right) and Machów (bottom right)

Rich sulfur deposits in the vicinity of Tarnobrzeg were discovered in 1954. This started the development of large-scale mining. In June 1966 for the first time in Poland the Frash method of underground borehole exploitation was applied. This caused the dynamic development of sulfur mining. The mine of Machów was established in 1968, as the forth one. The previously established mines were: Piaseczno, Grzybów and Jeziórko. In the mines of Machów and Piaseczno sulfur was exploited with the open cast method, while in other objects the Frash (borehole) method was applied (Krzaklewski et al., 1989; Pietrzykowski and Krzaklewski, 2012). In the second half of 1991 there was a rapid crackdown of the sulfur market. Consequently, the sulfur exploitation in the Jeziórko mine stopped, and in the following year the sulfur mine 
Machów also stopped mining. For the liquidated mine Jeziórko a forest and artificial water reservoirs based way of management and reclamation was accepted and for the sulfur mine Machów the way of reclamation was focused on agriculture and forestry based. The foothill of the repository and scarps went through forest reclamation while shelves between scarps and top parts of the hill were used for agricultural purposes (Krzaklewski et al. 1989).

\section{Materials and methods}

In the paper the following materials were used:

- airborne orthophotomaps (year 2009), pixel size $25 \mathrm{~cm}$, the coordinate system PUWG 1992; source District Centre of Surveying and Cartography

- satellite images of LANDSAT 7 (year 2000) and LANDSAT 8 (year 2013)

- vector layers of land use: Corine Land Cover 2000 and 2006, made available by the Main Inspectorate of the Environmental Protection cadastral data reviewed in the form of WMS layers in the GEOPORTAL service

- cadastral data reviewed in the form of WMS layers from the Forest Data Bank

- general economic map of the Forest In Stale covering the area of the sulfur mine Jeziórko in scale 1:10 000 (year 2003)

Based on the field vision the photointerpretation key was created - nomenclature of the classes of land cover was referring to the classification used in Corine Land Cover program. On-screen vectorization of the orthophotomap was carried out in ArcGIS 10.2 (ESRI) software, supervised pixel-based classification of satellite images LANDSAT was made in ILWIS, while GEOBIA in eCognition Developer (Trimble). For pixel-based classification the algorithms of Maximum likelihood was applied. The result was assessed in terms of accuracy (error matrix: Producer Accuracy, User Accuracy, Overall Accuracy and Kappa Coefficient) and went through filtration and generalization with the application of the tools of ILWIS and ArcGIS (among others Majority Filter and Boundary Clean). The GEOBIA was performed in a common approach of two stage process of segmentation and then the classification of the resulting segments (de Kok and Wężyk, 2008; Blaschke, 2010; Hay and Castilla, 2006). Multiresolution segmentation (Baatz and Schape, 2000) was used with the following parameters: Shape: 0.1, Compactness: 0.5. Four input bands of LANDSAT images were used in segmentation process (weights): Blue (1), Green (1), Red (3), NIR (1). The Scale parameter was varying from 3 for LANDSAT 7 images to 15-20 for LANDSAT 8. The workflow of the object-based classification is presented below (Fig. 2). Final results were made in ArcGIS to assess the participation of every class of land cover/use in the areas of the mines. 


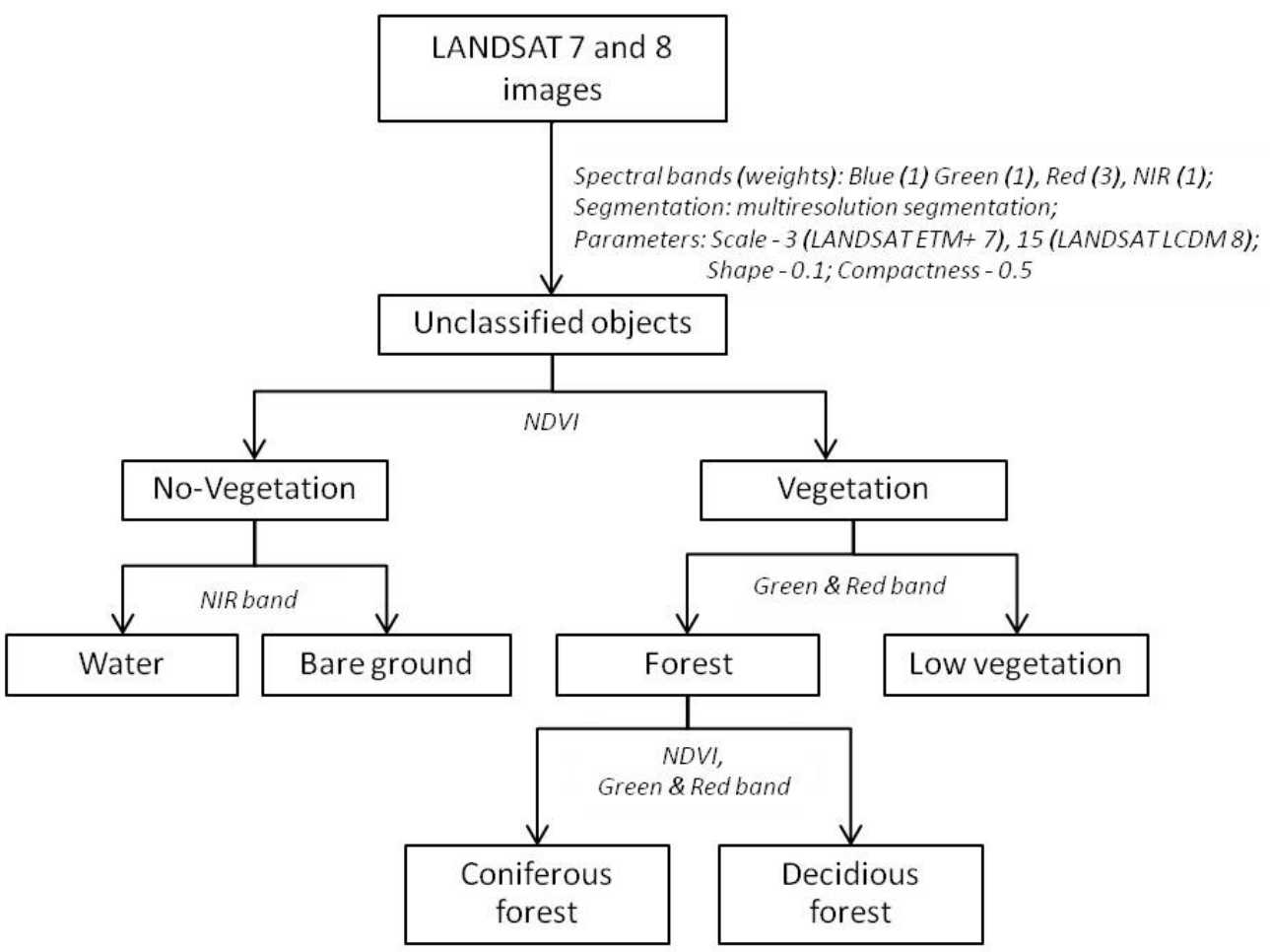

Fig. 2. The workflow of the object-based classification. The object features, which were most important for distinguishing the classes are given

\section{Results}

The distribution of LULC classes in the tested areas - sulfur mines Jeziórko and Machów, were obtained analysing the data from Corine Land Cover (CLC) 2000 and 2006, the LANDSAT images (LANDSAT 7 - year 2000 and LANDSAT 8 - year 2013) and airborne orthophotomaps (year 2009). The results show LULC changes in the tested areas in period $2000-2013$ (Table 1 and Table 2). In tables there were used short names of techniques and materials: CLC - Corine Land Cover; PIX L7, 8 - pixel-based classification of LANDSAT 7, 8; GEOBIA L7, 8 - Geographic Object Based Image Analysis of LANDSAT 7, 8; ORTO - on-screen vectorization of the orthophotomaps.

The most general materials referring to classes of land cover in the tested areas are data from Corine Land Cover 2000 and 2006. For mine Jeziórko (Table 1) there were only three classes: Mineral extraction sites $(73 \%$ of the tested area in year 2000 and $26 \%$ in 2006), Transitional woodland shrub (22\% in year 2000 and $68 \%$ in 2006) and Mixed Forests (5\%). More detail characteristics in the area of the land cover classes were obtained analysing the LANDSAT images and airborne orthophotomaps 
(Table 1). The results of GEOBIA and pixel-based classification of LANDSAT 7 (year 2000) indicate: Mineral extraction sites - above $70 \%$ of the studied area, Transitional woodland shrub - approx. 20\%, and the remaining area - Broad-leaved forest and Coniferous forest. The year 2009 (results of the orthophotomap on-screen vectorization; Fig 3. and 2013 (GEOBIA and pixel-based classification of LANDSAT 8 images; Fig. 5. brought a distinct growth of the class Forests with the decreases in classes: Transitional woodland shrub and Mineral extraction sites. Broad-leaved forest takes approx. 55\%, Coniferous forest take about 25\% while Mineral extraction sites merely about $2-7 \%$, Transitional woodland shrub cover $5 \%$ according to the orthophotomap vectorization and approx. $15 \%$ according to GEOBIA and pixelbased classification LANDSAT 8 images. On the orthophotomap also following classes were identified: Inland wetlands $-7 \%$ of the analysed area, Road and rail networks and associated land - 6.6\%, Mixed forest - 3.1\% and Agro-forestry areas $-0.9 \%$.

To make a comparison - for the mine of Machów (Table 2), manages in agricultural, in CLC 2000, 2006 there were classes: Arable land and Pastures approx. $70 \%$ of the whole study area, Forests approx. $23 \%$ and. $7 \%$ Transitional woodland shrub. GEOBIA and pixel-based classification of LANDSAT 7 (year 2000) revealed participation of each of the following classes: approx. 35\% Arable land, 25\% Pastures and $40 \%$ Forests. The results of on-screen vectorization of the orthophotomap (Fig. 4) and images classification of LANDSAT 8 (Fig. 5) mainly confirmed this class distribution - changes only in the participation of Pastures - 4\% (orthophotomap 2009) on favour of: Transitional woodland shrub - 20\% and Sparsely vegetated areas $-2 \%$.

For mines Machów and Jeziórko accuracy assessment (error matrix) of GEOBIA and pixel-based classification for LANDSAT 7 and 8 gave similar results for the both methods and materials. Kappa Coefficient amounted to approx. 85\% (exemplary results for accuracy assessment for pixel-based classification of LANDSAT 7 was: Producer Accuracy $=85.7 \%$, User Accuracy $=87.7 \%$, Overall accuracy $=86.3 \%$ for mine Jeziórko and Producer Accuracy $=88.3 \%$, User Accuracy $=88.6 \%$, Overall Accuracy $=84.9 \%$ for mine Machów). 
Table 1. The distribution [\%] of LULC classes in the tested area - sulfur mine Jeziórko

\begin{tabular}{|c|c|c|c|c|c|c|c|}
\hline \multirow{2}{*}{ Class (code CLC) } & \multicolumn{7}{|c|}{ The distribution [\%] of LULC Classes } \\
\hline & $\begin{array}{l}\text { CLC } \\
2000\end{array}$ & $\begin{array}{c}\text { PIX L7 } \\
2000\end{array}$ & $\begin{array}{l}\text { GEOBIA } \\
\text { L7 } 2000\end{array}$ & $\begin{array}{l}\text { CLC } \\
2006\end{array}$ & $\begin{array}{r}\text { ORTO } \\
2009\end{array}$ & $\begin{array}{l}\text { PIX L8 } \\
2013\end{array}$ & $\begin{array}{l}\text { GEOBIA } \\
\text { L8 } 2013\end{array}$ \\
\hline $\begin{array}{l}\text { Mineral extraction } \\
\text { sites }(131)\end{array}$ & 73.0 & 72.1 & 71.2 & 26.4 & 2.0 & 2.6 & 7.5 \\
\hline $\begin{array}{l}\text { Broad-leaved forest } \\
\text { (311) }\end{array}$ & \multirow{2}{*}{5.4} & 8.2 & 1.9 & \multirow{2}{*}{5.4} & 53.4 & 52.3 & 56.3 \\
\hline $\begin{array}{l}\text { Coniferous forest } \\
\text { (312) }\end{array}$ & & 3.0 & 2.5 & & 18.9 & 28.8 & 21.4 \\
\hline $\begin{array}{l}\text { Transitional } \\
\text { woodland shrub } \\
\quad(324)\end{array}$ & 21.6 & 16.2 & 24.4 & 68.2 & 5.4 & 15.7 & 14.4 \\
\hline Inland waters (51) & - & 0.5 & - & - & 2.4 & 0.6 & 0.4 \\
\hline \multicolumn{8}{|c|}{$\begin{array}{l}\text { Other classes distinguished only by on-screen digitalization of the orthophotomap: } \\
\text { Road and rail networks and associated land }(122)-6.6 \% \text {, Agro-forestry areas }(244)-0.9 \% \text {, } \\
\text { Mixed forest }(313)-3.1 \% \text {, Inland wetlands }(41)-7.3 \%\end{array}$} \\
\hline
\end{tabular}

Table 2. The distribution [\%] of LULC classes in the tested area - sulfur mine Machów

\begin{tabular}{|c|c|c|c|c|c|c|c|}
\hline \multirow{2}{*}{ Class (code CLC) } & \multicolumn{7}{|c|}{ The distribution [\%] of LULC Classes } \\
\hline & $\begin{array}{l}\text { CLC } \\
2000\end{array}$ & $\begin{array}{c}\text { PIX L7 } \\
2000\end{array}$ & $\begin{array}{l}\text { GEOBIA } \\
\text { L7 } 2000\end{array}$ & $\begin{array}{l}\text { CLC } \\
2006\end{array}$ & $\begin{array}{l}\text { ORTO } \\
2009\end{array}$ & $\begin{array}{l}\text { PIX L8 } \\
2013\end{array}$ & $\begin{array}{c}\text { GEOBIA } \\
\text { L8 } 2013\end{array}$ \\
\hline Arable lands (21) & \multirow{2}{*}{75.2} & 31.7 & 40.2 & \multirow{2}{*}{64.9} & 29.5 & 30.5 & 18.6 \\
\hline Pastures (23) & & 22.0 & 27.2 & & 4.2 & 18.4 & 17.2 \\
\hline $\begin{array}{l}\text { Broad-leaved forest } \\
\text { (311) }\end{array}$ & \multirow{2}{*}{19.1} & 44.1 & 30.3 & \multirow{2}{*}{26.6} & 37.2 & 49.1 & 58.2 \\
\hline $\begin{array}{c}\text { Coniferous forest } \\
\text { (312) }\end{array}$ & & 2.0 & 2.1 & & 0.5 & 1.4 & 0.2 \\
\hline $\begin{array}{l}\text { Transitional } \\
\text { woodland shrub } \\
\quad(324)\end{array}$ & 5.7 & - & - & 8.5 & 19.6 & - & - \\
\hline Inland waters (51) & - & 0.2 & 0.2 & - & 0.4 & 0.6 & 5.8 \\
\hline \multicolumn{8}{|c|}{$\begin{array}{l}\text { Other classes distinguished only by on-screen digitalization of the orthophotomap: } \\
\text { Discontinuous urban fabric }(112)-0.4 \% \text {, Road and rail networks and associated land (122) }-4.1 \% \text {, } \\
\text { Mineral extraction sites }(131)-1.7 \% \text {, Sparsely vegetated areas (333) }-2.3 \%\end{array}$} \\
\hline
\end{tabular}




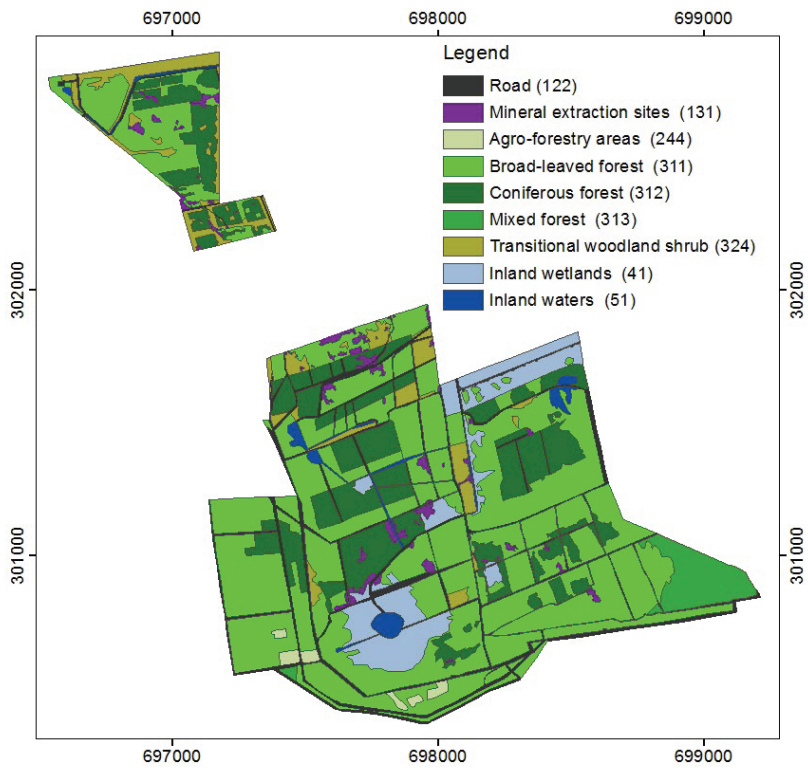

Fig. 3. LULC map - sulfur mine Jeziórko

(the result of on-screen digitalization of the orthophotomap)

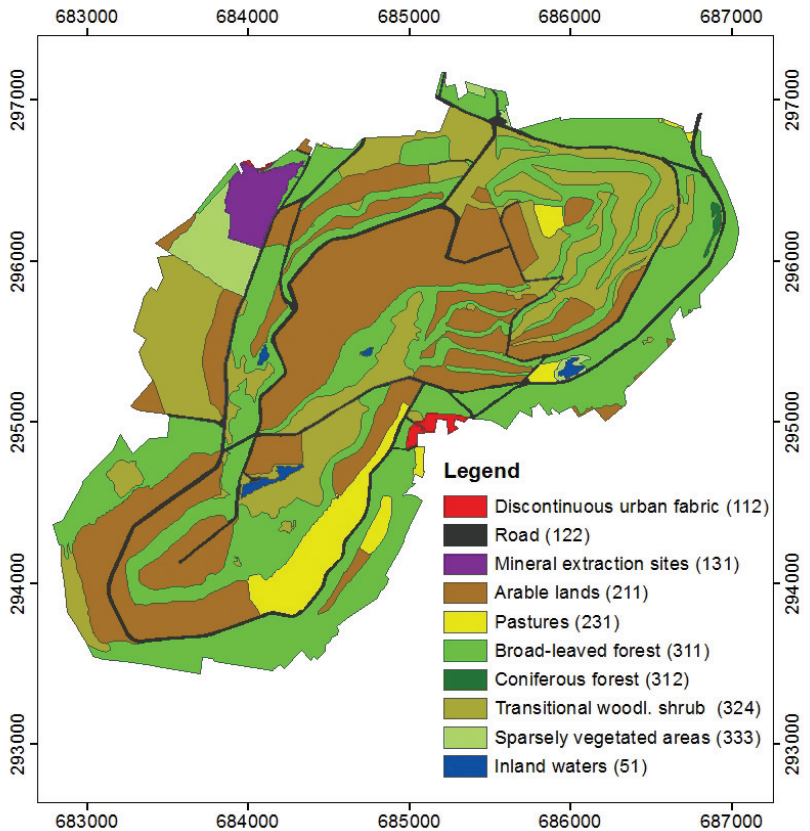

Fig. 4. LULC map - sulfur mine Machów

(the result of on-screen digitalization of the orthophotomap) 

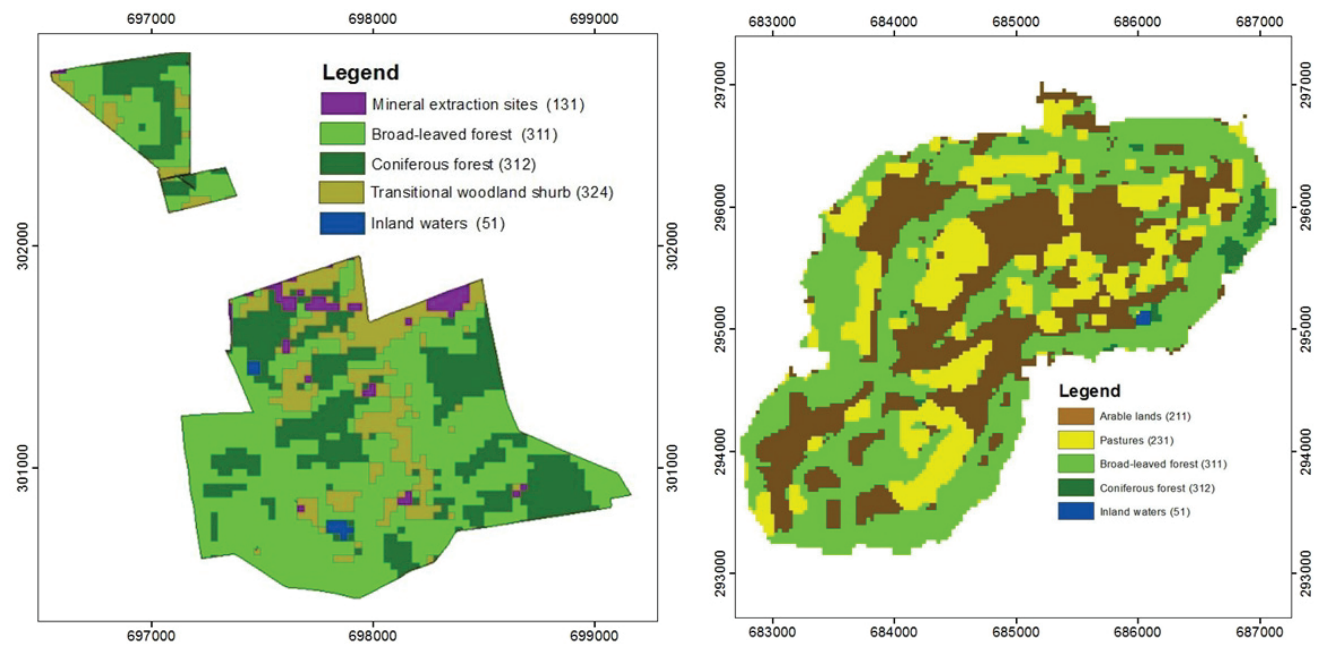

Fig. 5. The result of pixel-based classification of LANDSAT 8: the sulfur mines Jeziórko (left), and Machów (right)

\section{Conclusions}

Analysing LULC changes in the period of time 2000-2013 one can assess the effects of the reclamation projects realized for the objects of Jeziórko and Machów. In the area of the mine Jeziórko there is a significantly progressing forest-forming process and the occurrence of wetlands, according to the accepted forest way of reclamation. This direction was caused by the ground parameters - ground surface situated only a few metres higher than the ground water table. In many places where intensive exploitation subsidence occurred and troughs cutting the water table were formed, thus some areas were flooded (Hajdo et al., 2007). For the mine Machów the distribution of classes is similar to other studies on this area (Czarnecka and Duma, 2002) and confirms the reclamation in the direction of agriculture and forestry. In this area Forests and Arable land are dominant. The studies have showed the highly dynamic process of the secondary forest succession on the tested areas: sulfur mines Machów and Jeziórko.

Achieved land use/land cover classification accuracies of about $85 \%$ for both, pixel and object-based methods, are rather on low level. According to Anderson et all. (1976), 85\% is the minimum required classification accuracy when using LANDSAT data. The way to increase classification accuracy can be using of additional information like SAR data. Xia et all. (2011) based on data fusion approach of LANDSAT images and Radarsat data, achieved overall accuracy of 91.70\% (Kappa 87\%) for classification of Hongze Lake reclamation area. It is planned for further study to use SAR and optical data from Sentinel-1 and Sentinel-2 satellites for LULC classification of Jeziórko and Machów areas. 
The carried out classification of land cover with the application of geoinformation techniques in the areas of the reclaimed sulfur mines Jeziórko and Machów allowed the definition of the spatial range and direction of changes (including forest ecosystem succession process) in these areas. Both, on-screen vectorization of the orthophotomaps and classification of LANDSAT satellite images, provided the possibility to analyse the changes in land cover and land use, both of natural and human-controlled areas. The data obtained as a result of on-screen vectorization, pixel-based classification and GEOBIA are relatively similar. The choice of the proper method depends on the expected time of the realization, costs and effects of the categorization of the forms of land cover.

The evaluation of the reclamation process in the sulfur mines Machów and Jeziórko by means of geomatics, was not a specific purpose of the study. However, it can be stated that geoinformation technology provides useful tools for such kind of applications. Townsend et al., (2009) in their study about LULC mapping in Appalachians open surface mines area, indicated that LCLUC data can be useful for assessing the extent to which mining has resulted in flooding and associated expenses to structures and human livelihood. Management and monitoring of the natural environment, especially areas degraded by mining activities, is connected with the constant need for precise and up-to-date land use/land cover maps.

\section{Acknowledgments}

The article is based on own research conducted at the Faculty of Forestry, University of Agriculture in Krakow

\section{References}

Anderson, J. R., Hardy, E. E., Roach, J. T., and Witmer, R. E. (1976). A land use and land cover classification system for use with remote sensor data. Washington, DC: U.S. Geological Survey, No. Professional Paper 964.

Baatz, M., and Schape, A. (2000). Multiresolution Segmentation: an optimization approach for high quality multi-scale image segmentation. Journal of Photogrammetry and Remote Sensing, 58(3-4), $12-23$.

Bergen, K. M., and Dronova, I. (2007) Observing succession on aspen-dominated landscapes using a remote sensing-ecosystem approach. Landscape Ecology, 22, 1395-1410.

Blaschke, T., (2010). Object based image analysis for remote sensing. ISPRS Journal of Photogrammetry and Remote Sensing, 65(1), 2-16.

Chmielewski, S., Chmielewski, T. and Tompalski, P. (2014). Land cover and landscape diversity analysis in the West Polesie Biosphere Reserve. International Agrophysics, 28(2), 153-162. DOI:10.2478/ intag-2014-0003

Czernecka, A. and Duma, J. (2002). Master's thesis: „The assessment of the state of the management of the reclaimed external repository of the sulfur mine Machów”- supervision of Dr. Stanisław Kowalik, Eng., 2002. 
De Kok, R. and Wezyk, P. (2008). Principles of full autonomy in image interpretation. The basic architectural design for a sequential process with image objects. In T. Blaschke, S. Lang, and G. J. Hay (Eds.), Object-Based Image Analysis: Spatial Concepts for Knowledge-Driven Remote Sensing Applications (1st ed., 697-710). Berlin: Springer Berlin Heidelberg.

Drzewiecki, W., Wężyk, P., Pierzchalski, M. and Szafrańska B. (2014). Quantitative and Qualitative Assessment of Soil Erosion Risk in Małopolska (Poland), Supported by an Object-Based Analysis of High-Resolution Satellite Images. Pure Appl. Geophys., 171 (6), 867- 895. DOI: 10.1007/s00024013-0669-7

Dudzińska-Nowak, J. and Wężyk, P. (2014). Volumetric changes of a soft cliff coast 2008-2012 based on DTM from airborne laser scanning (Wolin Island, southern Baltic Sea). Journal of Coastal Research 04/2014, 70(SI), 59-64. DOI: 10.2112/SI70-011.1

Hajdo, S., Klich, J. and Galiniak G. (2007). Environmental and technological achievements in the 40-year history of the borehole mining sulfur in Poland. Mining and Geoengineering, Year 31, Issue 1.3 .

Hay, G. J., and Castilla, G. (2006). Object-based image analysis: strengths, weaknesses, opportunities and threats (SWOT). The International Archives of the Photogrammetry, Remote Sensing and Spatial Information Sciences, 36(4).

Hejmanowska, B. (2006). The use of remote sensing in monitoring the degraded areas by mining activities, New Mining, No. 1, www.nowegornictwo.pl

Krzaklewski, W., Chwastek, J., Golda, T. and Kowalik, S. (1989). Reclamation of mining lignite and sulfur. Economy Mineral Resources, 5(1), 269-291.

Pietrzykowski, M., Krzaklewski, W., Woś, B., and Pietrzak, W. (2012). Assessment of forest management of reclaimed areas after borehole sulfur. Przegląd Górniczy, Miesięcznik Stowarzyszenia Inżynierów i Techników Górnictwa, 7(68), 98-103.

Szostak, M. and Nowicka, M. (2013). The use of geo-technologies for land use mapping on reclaimed areas. Archive of Photogrammetry, Photogrammetry, Cartography and Remote Sensing, Vol. 25, 203-216.

Szostak, M. and Węzyk, P. (2013). GNNS measurements in forest environment using various receivers and measurement modes. Archive of Photogrammetry, Photogrammetry, Cartography and Remote Sensing, 25, 217-231.

Szostak, M., Wężyk P. and Tompalski P. (2014). Aerial Orthophoto and Airborne Laser Scanning as Monitoring Tools for Land Cover Dynamics: A Case Study from the Milicz Forest District (Poland). Pure and Applied Geophysics, 171(6), 857-866, DOI: 10.1007/s00024-013-0668-8

Tompalski, P., Coops N. C., White J. and Wulder, M.A. (2014). Simulating the impacts of error in species and height upon tree volume derived from airborne laser scanning data. Forest Ecology and Management, 09/2014, 327:167-177. DOI: 10.1016/j.foreco.2014.05.011

Townsend, P. A., Helmers, D. P., Kingdon, C. C., McNeil, B. E., de Beurs, K. M., and Eshleman, K. N. (2009). Changes in the extent of surface mining and reclamation in the Central Appalachians detected using a 1976-2006 LANDSAT time series. Remote Sensing of Environment, 113(1).

Wężyk, P. and Krzaklewski, W. (1999). Opportunities, problems and results of the use of digital photogrammetry techniques, GPS and GIS in land reclamation sand mine. Conference: Opencast mining - Environment - Reclamation - with particular regard to KWB Belchatow, Belchatow, 8-9. 06.1999, 147-154.

Wężyk, P., Krzaklewski W., and Wójcik J. (2014). Die 2D und 3D-Strukturen der Flora in der rekultievierten Gebieten anhand der Leserbefliegungen erfassten Punktenwolken. In: Cała M., von Bismarck F., Illing M. (Ed.): Geotechnische und Umweltaspekte bei der Rekultivierung und Revitalisierung von Bergbaufolgelandschaften in Polen und in Deutschland. Kraków, Wydawnictwa AGH, s. 108-123, 339-353.

Wężyk, P., Szostak M. and Tompalski, P. (2013). Use of Airborne Laser Scanning Data for a Revision and Update of a Digital Forest Map and its Descriptive Database: A Case Study from the Tatra 
National Park. The Carpathians: Integrating Nature and Society Towards Sustainability, Part IV, 615-627, Springer Berlin Heidelberg, DOI: 10.1007/978-3-642-12725-0_43

Xia, S., Ruan, R., Yan, M., and She, Y. (2011). Extraction of Hongze Lake Reclamation Area Based on RADARSAT SAR and LANDSAT ETM+. Procedia Environmental Sciences, 10, Part C, 22942300 .

\title{
Określenie przestrzenno - czasowych zmian pokrycia i użytkowania terenów rekultywowanych w oparciu o lotnicze ortofotomapy i zobrazowania LANDSAT
}

\author{
Marta Szostak $^{1}$, Piotr Wężyk ${ }^{1}$, Pawel Hawryło ${ }^{1}$, Marcin Pietrzykowski ${ }^{2}$ \\ ${ }^{1}$ Uniwersytet Rolniczy w Krakowie, Wydział Leśny \\ Instytut Zarządzania Zasobami Leśnymi \\ Zakład Urządzania Lasu, Geomatyki i Ekonomiki Leśnictwa - Laboratorium Geomatyki \\ Aleja 29 Listopada 46, 31-425 Kraków \\ e-mail: m.szostak@ur.krakow.pl; p.wezyk@ur.krakow.pl; p.hawrylo@ur.krakow.pl \\ ${ }^{2}$ Uniwersytet Rolniczy w Krakowie, Wydział Leśny \\ Instytut Ekologii i Hodowli Lasu \\ Zakład Ekologii Lasu i Rekultywacji \\ Aleja 29 Listopada 46, 31-425 Kraków \\ e-mail: rlpietrz@cyf-kr.edu.pl
}

\section{Streszczenie}

Celem badań było określenie możliwości wykorzystania ogólnie dostępnych geodanych dla opracowywania map pokrycia i użytkowania terenu obszarów zrekultywowanych. Wybór tematu był podyktowany rosnącą liczbą takich obszarów i częstym problemem przywrócenia lub nadania gruntom poprzemysłowym wartości użytkowych (wykonanie rekultywacji). Określano zasadność wykorzystania technologii geoinformatycznych oraz materiałów fotogrametrycznych i teledetekcyjnych dla wyznaczenia granic klas pokrycia terenu, istotnych w ocenie efektów rekultywacji oraz analizach zmian zachodzących na tego rodzaju obiektach. Opracowanie wykonano dla zwałowiska zewnętrznego Kopalni Siarki „Machów” oraz obszaru zrekultywowanej Kopalni Siarki „Jeziórko”, leżących w powiecie tarnobrzeskim. Podstawowymi materiałami badawczymi były ortofotomapy lotnicze, na postawie których wykonano wektoryzację ekranową klas pokrycia terenu; zobrazowania satelitarne LANDSAT 7 i 8, które posłużyły do przeprowadzenia klasyfikacji pikselowej i obiektowej oraz dane programu CORINE Land Cover, jako ogólne odniesienie do globalnych map pokrycia i użytkowania terenu. 